\title{
Competências Conversacionais para a Governança Corporativa
}

\author{
José Coelho Ávila', Gentil José Lucena Filho ${ }^{2}$, Rejane Maria da Costa Figueiredo ${ }^{3}$ \\ ${ }^{1}$ Senado Federal - Brasília, Brazil \\ ${ }^{2}$ LabCon - Laboratório de Conversas, Brasília, Brazil \\ ${ }^{3}$ ITRAC - Information Technology, Research and Application Center, FGA - \\ Faculdade Gama, UnB - Universidade de Brasília, Brasília, Brazil \\ jcavila12@gmail.com, gentil@labconbrasil.com, rejanecosta@unb.br
}

\begin{abstract}
Corporate governance is being placed as a tool for organizations' realignment on a global context of cultural and values changes. Paradoxically it carries historical traditions and technicist methods that face before a scenario where organizations seek to humanize their relations. How then integrate human and social issues and technical issues in order to obtain more effective results? This article presents a study on technical and ontological framework where, by means of conversational skills, leaders and managers are responsible for address this integration. The theories and real case study presented in this article show the importance of conversations for Corporate Governance and effectiveness of the results of organizations.
\end{abstract}

Resumo. Governança corporativa é um instrumento de realinhamento das organizações num contexto global de mudanças culturais e de valores. Paradoxalmente, junto vem uma tradição histórica e de métodos tecnicistas que não condizem com um cenário onde as organizações buscam humanizar suas relações. Como então integrar questões humanas e sociais com questões técnicas de forma a obter resultados mais efetivos? Este artigo apresenta um estudo sobre um framework técnico e ontológico onde, via competências conversacionais, líderes e gestores assumem cuidar dessa integração. As teorias e estudo de caso real apresentados mostram a importância $e$ efetividade das conversações na Governança Corporativa e seus resultados.

\section{Introdução}

A Governança Corporativa (GC), conforme a Organização para a Cooperação e Desenvolvimento Econômico, OCDE (2004), Brasil (2007) e o Instituto Brasileiro de Governança Corporativa - IBGC (2009), tem como objetivo alinhar as ações dos gestores aos interesses da organização e das partes interessadas em relação à propriedade, aos resultados e ao melhor desempenho, envolvendo tanto problemas técnicos - relacionados a aspectos técnicos, em geral fáceis de identificar, de serem aceitos e que podem ser resolvidos por uma autoridade reconhecida ou especialista tais como fatores como direcionamento, monitoramento, fiscalização e controle, -

ÁVILA, J. C.; LUCENA FILHO, G. J.; FIGUEIREDO, R. M. C.

Competências Conversacionais para a Governança Corporativa

isys | Revista Brasileira de Sistemas de Informação, Rio de Janeiro, vol. 10, No. 2, pp. $85-110,2017$ 
quanto desafios adaptativos - associados a fatores humanos e sociais, em geral difíceis de identificar (e pouco reconhecidos, facilmente rejeitados), para serem resolvidos requerem mudanças em valores, crenças, papéis, relacionamentos, abordagens, princípios e comportamentos [Heifetz e Laurie 1997].

Ao estudar a Governança Corporativa e os meios para se atingir esses fins, este trabalho identificou que desafios genuinamente adaptativos relacionados à governança estão sendo tratados de forma tecnicista, como se fossem problemas técnicos. O que tem se verificado, segundo o IBGC (2009), é a tentativa de converter princípios, valores e comportamentos, por exemplo, em práticas de direcionamento, monitoração e controle, ou alinhar o comportamento de gestores por meio de regras, mecanismos de controle, incentivos e punições.

A questão que surge é se esses "ajustes" no "fazer" das práticas da Governança Corporativa serão suficientes para promover e estabelecer mudanças de cultura e de comportamento no "ser" que, em última instância, é quem faz acontecer os resultados organizacionais. Autores como Heifetz e Laurie (1997), Migueles et al. (2009), Sznifer (2012) e Echeverría (1999) afirmam que estamos em um cenário de mudanças para uma sociedade do conhecimento, baseada no capital intelectual. Essas mudanças culturais exigem uma liderança que atue de forma diferenciada da forma tradicional, onde se aprendeu durante séculos o poder da hierarquia, da coerção e do controle.

Diante desse quadro, considera-se que as dimensões adaptativas (ou ontológicas) e técnicas devam ser cuidadas de forma integrada, mas diferenciada, respeitando suas naturezas, para que se possam levar a cabo as mudanças culturais e comportamentais e, assim, atingir os resultados esperados. Os pressupostos dessa pesquisa é que as competências conversacionais oferecem os elementos fundamentais e essenciais para cuidar da dimensão adaptativa ou ontológica. E para fazer a gestão integrada aspectos ontológicos e técnicos relacionados à Governança, frameworks como o Modelo de Gestão Ontológica proposto por Hidalgo (2009) e seus derivados, como o trabalho desenvolvido por Lucena Filho e colaboradores [Lucena filho et al. 2012] são instrumentos adequados.

Nesta pesquisa fez-se uso desses instrumentos e cunhou-se o termo "framework tecnontológico" criado por Lucena Filho, e apresentado em Lucena Filho et al. (2012) para investigar como as competências conversacionais podem contribuir para a Governança Corporativa e adequar suas ações ao novo contexto das organizações. Para tanto, realizou-se um estudo bibliográfico e uma pesquisa aplicada a um grupo específico em um ambiente de execução de projetos para implantação da Governança Corporativa em um órgão do Poder Legislativo na esfera da administração pública federal.

Os resultados apresentados mostram a importância e o poder das competências conversacionais para os objetivos da Governança Corporativa, a carência dessas competências no ambiente organizacional e a aplicabilidade do framework mencionado para a gestão das conversas e integração das dimensões técnicas e ontológicas, ou adaptativas.

Este artigo está organizado em 5 seções. Na Seção 2 apresenta-se o referencial teórico deste trabalho, tratando de conceituar e situar a Governança Corporativa em seu 
contexto histórico e seu campo de atuação para, em seguida, apresentar e conceituar o framework tecnontológico como instrumento de gestão das questões tecnológicas e ontológicas abraçadas pela Governança Corporativa. Na Seção 3 apresentam-se os materiais e métodos adotados. Na Seção 4 apresenta-se a análise dos resultados alcançados. Na Seção 5, as considerações finais

\section{Referencial Teórico}

\subsection{Uma História}

Para se entender porque questões ontológicas são tratadas de modo tecnicista cabe observar que do século XVIII ao XX predominou nas organizações a visão mecanicista, fundamentada principalmente em comando, coordenação e controle. Essa visão, ao considerar a organização como um processo racional e técnico, tende a subestimar os aspectos humanos e negligenciar o fato de que as tarefas nas e das organizações são muito mais complexas, incertas e difíceis do que as desempenhadas pela maioria das máquinas [Morgan 2002].

Os fundamentos da teoria da administração foram fortemente marcados por duas características predominantes da época: a estrutura hierárquica, herdada dos instrumentos de controle e dominação de massa conhecidos na época: impérios, igrejas e exércitos; e a burocracia, "composto pelo francês, bureau (escritório) e pelo grego, krátos (poder ou regra), significando o exercício do poder por funcionários de escritórios" [Morgan 2002].

Burocracia é a delegação do poder de decisão de um ator principal (proprietário ou acionista, na iniciativa privada, sociedade ou cidadão, no setor público) para um agente especializado (gestor ou administrador). A partir do momento em que ocorre essa delegação, constata-se o risco do assim chamado "conflito de agência", pois nem sempre os interesses do agente especializado estarão alinhados com os do ator principal.

A Governança Corporativa surgiu para superar esse conflito. À medida que fomos nos aproximando do século XXI, houve a desconstrução das burocracias, de valores e tradições culturais, motivada pelas consequências disfuncionais nas organizações, pela injustiça social e pelo desequilíbrio na distribuição das riquezas [Morgan 2002]. Essa desconstrução, em que pese seu propósito de criar uma sociedade mais justa, reduzindo as possibilidades de "coerção direta de um ser humano sobre o outro" [Migueles et al. 2009], também abriu portas para uma série de fraudes contábeis e escândalos empresariais que resultaram em fracassos corporativos ou em significativa destruição de valor.

O movimento iniciado nos anos 90 retoma o conceito de Governança Corporativa, estabelecendo novas regras que, conforme o IBGC (2009), protegessem os acionistas dos abusos da diretoria executiva das empresas, da inércia de conselhos de administração inoperantes e das omissões das auditorias externas, porém o modelo utilizado carrega os conceitos mecanicistas e tecnicistas como veremos a seguir. 


\title{
2.2. Um Fim
}

As conceituações de organizações vindas de autores e instituições como a Organização para a Cooperação e Desenvolvimento Econômico, OCDE (2004), Weill e Ross (2006), Brasil (2007), IBGC (2009) e a Information Systems Audit and Control Association, ISACA (2012), mostram que o movimento da Governança Corporativa abrange não só questões ontológicas - como esforços orientados a tentativa de definição de relações entre principal e agente, o estímulo a comportamentos desejáveis e o estabelecimento de condições para que objetivos equilibrados sejam acordados e alcançados - como também questões técnicas - como ações orientadas ao estabelecimento de um sistema de estruturas, papéis e responsabilidades para decisão, direção, monitoração, controle e fiscalização -, tudo isso com a finalidade de proteger os direitos do ator principal, otimizar o desempenho da empresa, maximizar os resultados econômico-sociais, preservar valor da organização e contribuir para sua longevidade.

Exemplos do olhar técnico sobre a questão ontológica podem ser vistos na definição do IBGC (2009), como: "As boas práticas de Governança Corporativa convertem princípios em recomendações objetivas [...]" e no próprio sítio do IBGC (http://www.ibgc.org.br/):

\begin{abstract}
"A preocupação da Governança Corporativa é criar um conjunto eficiente de mecanismos, tanto de incentivos quanto de monitoramento, a fim de assegurar que o comportamento dos executivos esteja sempre alinhado com o interesse dos acionistas". (http://www.ibgc.org.br/Secao.aspx?CodSecao=18).
\end{abstract}

No Quadro 1 apresenta-se uma coletânea de conceitos de Governança Corporativa apresentados por diferentes autores.

\section{Quadro 1 - Conceituações de Governança}

\begin{tabular}{|c|c|c|}
\hline Organização & Conceituação & Fonte \\
\hline $\begin{array}{l}\text { OCDE - Organização } \\
\text { para a Cooperação e o } \\
\text { Desenvolvimento } \\
\text { Econômico }\end{array}$ & $\begin{array}{l}\text { Governança corporativa corresponde ao conjunto de relações entre a } \\
\text { administração de uma empresa, seu conselho administrativo, seus } \\
\text { acionistas e outras partes interessadas, proporcionando a estrutura que } \\
\text { define os objetivos da empresa, como atingi-los e como fiscalizar o seu } \\
\text { desempenho. }\end{array}$ & $\begin{array}{c}\text { [OCDE } \\
2004]\end{array}$ \\
\hline $\begin{array}{l}\text { Estudos em } 256 \\
\text { empresas, em vários } \\
\text { continentes, em vários } \\
\text { setores econômicos, } \\
\text { entre } 2001 \text { e } 2003 .\end{array}$ & $\begin{array}{l}\text { Definimos a Governança de TI como a especificação dos direitos } \\
\text { decisórios e do framework de responsabilidades para estimular } \\
\text { comportamentos desejáveis na utilização de TI. A Governança de } \\
\text { TI não consiste na tomada de decisões específicas sobre a } \\
\text { Tecnologia da Informação - a administração já faz isso -, mas } \\
\text { determina quem sistematicamente toma tais decisões e contribui para } \\
\text { elas. }\end{array}$ & $\begin{array}{l}\text { [Weill e } \\
\text { Ross } \\
\text { 2006] }\end{array}$ \\
\hline $\begin{array}{l}\text { Criação da CGPAR - } \\
\text { Comissão } \\
\text { Interministerial de } \\
\text { Governança } \\
\text { Corporativa e de Adm. } \\
\text { de Participações } \\
\text { Societárias da União }\end{array}$ & $\begin{array}{l}\text { Governança corporativa: conjunto de práticas de gestão, } \\
\text { envolvendo, entre outros, os relacionamentos entre acionistas ou } \\
\text { quotistas, conselhos de administração e fiscal, ou órgãos com } \\
\text { funções equivalentes, diretoria e auditoria independente, com a } \\
\text { finalidade de otimizar o desempenho da empresa e proteger os } \\
\text { direitos de todas as partes interessadas, com transparência e } \\
\text { equidade, com vistas a maximizar os resultados econômico-sociais } \\
\text { da atuação das empresas estatais federais. }\end{array}$ & 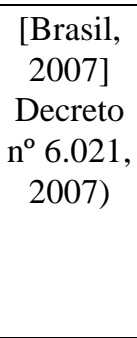 \\
\hline $\begin{array}{l}\text { IBGC }- \text { Instituto } \\
\text { Brasileiro de } \\
\text { Governança } \\
\text { Corporativa }\end{array}$ & $\begin{array}{l}\text { Governança Corporativa é o sistema pelo qual as organizações são } \\
\text { dirigidas, monitoradas e incentivadas, envolvendo os } \\
\text { relacionamentos entre proprietários, Conselho de Administração, } \\
\text { Diretoria e órgãos de controle. As boas práticas de Governança }\end{array}$ & $\begin{array}{c}\text { [IBGC } \\
2009]\end{array}$ \\
\hline
\end{tabular}


Corporativa convertem princípios em recomendações objetivas, alinhando interesses com a finalidade de preservar e otimizar o valor da organização, facilitando seu acesso a recursos e contribuindo para sua longevidade.

Cobit 5 Governança assegura que as necessidades das partes interessadas, as [ISACA condições e as opções sejam avaliadas para que os objetivos 2012] equilibrados e acordados da organização sejam alcançados; estabelecendo a direção por meio de prioridades e tomada de decisão; e monitorando o desempenho e a conformidade de acordo com a direção e objetivos acordados.

Fonte: Os autores.

Entendida a finalidade, apresenta-se a seguir os meios pelos quais tem se buscado a efetivação da visão da Governança Corporativa.

\subsection{Os Meios}

Segundo fontes relacionadas no Quadro 2, como a Comissão de Valores Mobiliários, CVM (2002), o IBGC (2009), a OCDE (2004), Weill e Ross (2006), o Committee of Sponsoring Organizations of the Treadway Commission, COSO (2007), e o Tribunal de Contas da União (Brasil (2013), as tentativas de soluções buscadas para a Governança Corporativa passam por práticas tais como recomendações, orientações e princípios para serem seguidos, estabelecimento de normas mais rígidas, códigos de ética, responsabilização da alta gestão, penalidades mais graves, exigências de informação sobre adesão a práticas de governança e ciclos de avaliação, classificação e segmentação de organizações em listagens especiais. Em geral, as práticas sugeridas recaem sobre o arranjo das estruturas de conselhos de administração, conselhos fiscais, comitês, gestores e auditoria independente, sobre mecanismos de liderança, gerenciamento de riscos, controle, fiscalização e auditoria.

Quadro 2 - Meios utilizados para se fazer a governança corporativa

\begin{tabular}{|c|c|c|c|}
\hline Fato & Ano & Meios utilizados & Fonte \\
\hline Relatório Cadbury & 1992 & $\begin{array}{l}\text { Recomendações sobre o arranjo dos conselhos } \\
\text { administrativos e sistemas contábeis para mitigar os } \\
\text { riscos e fracassos relacionados à governança } \\
\text { corporativa }\end{array}$ & $\begin{array}{l}\text { [Cadbury } \\
\text { Report } \\
1992]\end{array}$ \\
\hline $\begin{array}{l}\text { Princípios da OCDE } \\
\text { sobre o Governo das } \\
\text { Sociedades }\end{array}$ & 1999 & $\begin{array}{l}\text { Princípios para serem seguidos por Estados-Membros e } \\
\text { países terceiros; orientação específica para as } \\
\text { iniciativas legislativas e regulamentadoras; normas } \\
\text { fundamentais para sistemas financeiros sólidos. }\end{array}$ & $\begin{array}{l}\text { [OCDE } \\
2004]\end{array}$ \\
\hline $\begin{array}{l}\text { Reformulação da Lei } \\
\text { das Sociedades } \\
\text { Anônimas }\end{array}$ & 2001 & $\begin{array}{l}\text { A Bolsa de Valores de São Paulo criou "segmentos } \\
\text { especiais de listagem destinados a empresas com } \\
\text { padrões superiores de Governança Corporativa" com o } \\
\text { objetivo de "de estimular o interesse dos investidores e } \\
\text { a valorização das empresas listadas". }\end{array}$ & $\begin{array}{l}\text { (www.ibg } \\
\text { c.org.br/Se } \\
\text { cao.aspx? } \\
\text { CodSecao } \\
\quad=20)\end{array}$ \\
\hline $\begin{array}{l}\text { Lei Sarbanes-Oxley, de } \\
30 \text { de julho de } 2002 \text {. }\end{array}$ & 2002 & $\begin{array}{l}\text { Normas mais rígidas para a auditoria de empresas } \\
\text { públicas; responsabilização da alta gestão é pela } \\
\text { exatidão da informação financeira; penalidades mais } \\
\text { graves para a atividade financeira fraudulenta; } \\
\text { ampliação do papel de supervisão dos conselhos de } \\
\text { administração. }\end{array}$ & $\begin{array}{l}\text { Lei } \\
\text { Sarbanes- } \\
\text { Oxley, } \\
2002\end{array}$ \\
\hline
\end{tabular}




\begin{tabular}{|c|c|c|c|}
\hline Fato & Ano & Meios utilizados & Fonte \\
\hline $\begin{array}{l}\text { Cartilha sobre o tema } \\
\text { Governança } \\
\text { Corporativa }\end{array}$ & 2002 & $\begin{array}{l}\text { Recomendações da Comissão de Valores Mobiliários } \\
\text { (CVM), relativas a boas práticas de Governança } \\
\text { Corporativa; exigência de informação anual sobre o } \\
\text { nível de adesão às recomendações. }\end{array}$ & $\begin{array}{l}{[\mathrm{CVM}} \\
2002]\end{array}$ \\
\hline $\begin{array}{l}\text { Estudos em } 256 \\
\text { empresas, em vários } \\
\text { continentes, em vários } \\
\text { setores econômicos, } \\
\text { entre } 2001 \text { e } 2003 \text {. }\end{array}$ & 2003 & $\begin{array}{l}\text { "As empresas implementam seus arranjos de } \\
\text { governança por meio de um conjunto de mecanismos } \\
\text { de governança - estruturas, processos e } \\
\text { comunicaçôes. Mecanismos bem concebidos, bem } \\
\text { compreendidos e transparentes promovem } \\
\text { comportamentos desejáveis em termos de TI". }\end{array}$ & $\begin{array}{c}\text { [Weill e } \\
\text { Ross } 2006\end{array}$ \\
\hline $\begin{array}{l}\text { COSO (Committee of } \\
\text { Sponsoring } \\
\text { Organizations of the } \\
\text { Treadway } \\
\text { Commission) }\end{array}$ & 2004 & $\begin{array}{l}\text { Estrutura integrada para gerenciamento de riscos } \\
\text { corporativos a fim de melhorar a capacidade de gerar } \\
\text { valor. Considera aspectos críticos da governança } \\
\text { corporativa, ética empresarial, controle interno, gestão } \\
\text { de risco empresarial, fraude e relatórios financeiros. }\end{array}$ & $\begin{array}{c}{[\mathrm{COSO},} \\
2007]\end{array}$ \\
\hline $\begin{array}{l}\text { Código das melhores } \\
\text { práticas de governança } \\
\text { corporativa }\end{array}$ & 2009 & $\begin{array}{l}\text { Funcionamento do sistema de governança corporativa: a } \\
\text { composição e atribuições dos agentes de governança } \\
\text { (conselho de administração, conselho fiscal, gestores e } \\
\text { auditoria independente) e os quatro princípios básicos } \\
\text { da boa governança: transparência, equidade, prestação } \\
\text { de contas (accountability) e responsabilidade } \\
\text { corporativa. }\end{array}$ & $\begin{array}{c}{[\mathrm{IBGC}} \\
2009]\end{array}$ \\
\hline $\begin{array}{l}\text { Tribunal de Contas da } \\
\text { União (TCU) }\end{array}$ & $\begin{array}{l}2007 \\
2010 \\
2012\end{array}$ & $\begin{array}{l}\text { O TCU instituiu um processo de acompanhamento e } \\
\text { de indução ao amadurecimento da governança e da } \\
\text { gestão, baseado no Programa Nacional de Gestão } \\
\text { Pública e Desburocratização (GesPública) e em } \\
\text { modelos de boas práticas reconhecidos } \\
\text { internacionalmente. }\end{array}$ & $\begin{array}{c}\text { [BRASIL } \\
\text { 2013] }\end{array}$ \\
\hline
\end{tabular}

Fonte: Os autores.

O que tem se observado é que, em geral, as "práticas da governança" se distanciam dos "princípios, valores e diretrizes", não pelo fim em si, mas pelos meios utilizados. Um exemplo do olhar técnico sobre a questão ontológica pode ser visto na definição do IBGC (2009) que menciona que "as boas práticas de Governança Corporativa convertem princípios em recomendações objetivas" e que a preocupação da Governança Corporativa é criar um conjunto eficiente de mecanismos, tanto de incentivos quanto de monitoramento, a fim de assegurar que o comportamento dos executivos esteja sempre alinhado com o interesse dos acionistas.

O risco dessa abordagem é incorrer em resultados pouco efetivos, pois se foca no controle do "fazer" dos executivos e se distancia da mudança essencial do "ser". Esse distanciamento do ser humano é característico do mundo mecanicista. Segundo Max Weber, citado por Morgan (2002), a rotinização e a mecanização dos aspectos da vida humana corroem o espírito humano e a capacidade de ação espontânea.

\subsection{O Cenário}

A transição do cenário de uma sociedade industrial (um sistema de produção em massa com o capital centrado na propriedade) para uma sociedade do conhecimento (um 
sistema de produção baseado no conhecimento e no capital intelectual) exige uma transição da natureza das relações de trabalho, da aplicação de mecanismos de controle coercitivos para os mecanismos sociais baseados em consenso [Migueles et al. 2009]. O foco no resultado não é uma questão meramente racional, mas também é "um processo afetivo de se lidar com coragem e com risco que são aspectos mais emocionais do que racionais" [Sznifer 2012]. Já não se trata apenas de operar com maior racionalidade cognitiva, mas também de "desenvolver a capacidade emocional" [Kofman 2002]. A nova geração de negócios está voltada para as conveniências dos clientes e a nova geração de empresas voltada à "capacidade de gerir compromissos e redes de relacionamento" [Flores 1996].

As organizações se constituem o principal motor das transformações históricas e, consequentemente, estão desafiadas por sua própria transformação e pela responsabilidade de construção do futuro [Echeverría 1999]. Diante desse quadro, este trabalho busca nas competências conversacionais os instrumentos para que governantes, gestores e gerentes atuem com efetividade dentro desse cenário.

\subsection{O Instrumento}

A importância da linguagem como fator de geração de mudanças, ações e resultados é citada por vários autores. Echeverría (2005) afirma que afirmações, declarações, ofertas, pedidos e promessas são atos linguísticos fundamentais e que, na sociedade do conhecimento, o trabalhador do conhecimento não pode prescindir de ter competências conversacionais.

Competência conversacional, segundo Lucena Filho et al. (2012), é:

"A capacidade de, conversando, mobilizar, articular e colocar em ação, de forma sustentável, valores, conhecimentos, habilidades e atitudes necessários para o desempenho eficiente e eficaz de atividades requeridas no trabalho e na vida, de maneira geral." [Lucena Filho et al. 2012].

Pressupõe-se que, para a Governança Corporativa atingir resultados mais efetivos é preciso cuidar das conversas. É preciso que os governantes, em qualquer nível, desenvolvam suas competências conversacionais. Para ajudar na gestão das conversas nas organizações, Lucena Filho e alguns colaboradores [Lucena Filho et al. 2012] conceberam e desenharam um framework baseado na concepção das organizações como redes de compromissos de Winograd e Flores (1988), nas dimensões estruturais de compromissos apontadas por Kofman (2002) e nos cinco domínios ontológicos da gestão de Hidalgo (2009). Apresenta-se a seguir as fundamentações.

\subsubsection{A organização como uma rede de compromissos}

Winograd e Flores (1988) consideram que a organização corresponde a uma rede de compromissos e que os gestores são responsáveis por articular e ativar esses compromissos dentro da rede. As conversas são essenciais para cuidar dos compromissos, com uma abordagem participativa, abertura para o novo e capacidade de ouvir. Isto significa que "o papel dos gestores deve tratar não apenas de tarefas, mas também, e principalmente, das relações interpessoais que surgem ao realizar essas tarefas" [Lucena Filho et al. 2012]. 


\subsubsection{Cada compromisso tem três dimensões (T-R-I)}

Kofman (2002) considera que os compromissos conversacionais afetam três níveis. No nível da Tarefa (T) se coordenam as ações para gerar resultados, no nível das Relações (R) se estabelecem vínculos de confiança e no nível da Identidade (I) se cuida que as ações sejam realizadas com dignidade e integridade, ou seja, com coerência entre a intenção e a ação. Lucena Filho et al. (2012) entendem que tarefa, relações e identidade são dimensões de uma estrutura sobre a qual as organizações se manifestam, ressaltando que uma quebra ou desequilíbrio em apenas uma dimensão compromete o resultado final.

\subsubsection{Os cinco domínios da Gestão Ontológica}

Para sustentar as dimensões dos compromissos organizacionais Lucena Filho et al. (2012) se utilizam do "ciclo de Gestão Ontológica" de Hidalgo (2009), definido em cinco domínios de conversação que devem ser considerados de forma complementar e aos quais Lucena Filho et al. (2012) associam um conjunto de competências conversacionais.

O domínio da (Realidade) ${ }^{1}$, onde os problemas são observados e compartilhados conforme as distinções que cada um é capaz de fazer e cujas competências são fazer afirmações verdadeiras, comprováveis e relevantes, estar aberto para acolher novas distinções e conexões, e atuar a partir da ética do respeito pelas diferenças.

O domínio das Possibilidades, onde se abre o campo de visão para a busca de soluções e cujas competências residem na capacidade de suspender os julgamentos, criar um ambiente de criatividade e inovação, fazer declarações válidas, emitir juízos bem fundamentados e atuar em coerência com ambos, declarações e juízos. Aqui se estabelece o comprometimento: comportamento consistente e autoridade condizente com as declarações feitas.

O domínio da Ação e Resultados, onde surge a ação que vai gerar resultados efetivos e cujas competências residem em ser capaz de compreender e implementar o ciclo de coordenação de ações; saber criar contexto, negociar, cumprir (e fazer cumprir) as promessas feitas; saber avaliar; saber reclamar; saber declarar; saber construir e reconstruir confiança e cuidar da identidade própria e dos outros.

O domínio dos Relacionamentos, onde são consideradas as interações entre as pessoas e cujas competências residem na capacidade de reconhecer e antecipar quiebres, que são interrupções nas interações entre as pessoas. Quando ocorre um quiebre, a ação deixa de fluir, ou uma nova ação toma lugar para se aproveitar uma oportunidade. $\mathrm{O}$ gestor deve estar atento e gerar um ambiente onde a essência da ética, a satisfação e a lealdade sejam mantidas.

E o domínio da Aprendizagem, que trata do desenvolvimento contínuo da capacidade de atuação e cuja competência reside na habilidade de emitir e receber

\footnotetext{
${ }^{1}$ A denotação da (Realidade) - leia-se: Realidade entre parêntesis - vem de Maturana, para ressaltar o fato de que não existe uma "realidade" última, nem única, nem objetiva. A "realidade", quando assim referida por alguém, está sempre condicionada à visão do sujeito que a distingue e, por isso, é sempre subjetiva.
} 
avaliações e juízos de forma respeitosa e na capacidade de estar sempre preparado para aprender, como uma ação consciente, acompanhada de um pensar, um sentir e um querer verdadeiro.

\subsubsection{O Framework Conversacional}

O Framework de Gestão das Conversações que Lucena Filho et al. (2012) conceberam está resumido no Quadro 3. No cruzamento de cada domínio da Gestão Ontológica (linhas) com cada dimensão dos compromissos organizacionais (colunas), a célula traz um conjunto de distinções básicas de conversação.

Quadro 3 - Framework de gerenciamento das conversações para GC

\begin{tabular}{|c|c|c|c|}
\hline Domínios & Tarefa & Relações & Identidade \\
\hline $\begin{array}{l}\text { Domínio da } \\
\text { (Realidade) }\end{array}$ & $\begin{array}{l}\text { (Realidade), distinções, } \\
\text { informação e afirmações }\end{array}$ & $\begin{array}{c}\text { Distinções novas } \\
\text { e conexão }\end{array}$ & Respeito \\
\hline $\begin{array}{l}\text { Domínio das } \\
\text { Possibilidades }\end{array}$ & $\begin{array}{l}\text { Suspender julgamentos, } \\
\text { decidir e declarar }\end{array}$ & $\begin{array}{c}\text { Coerência entre } \\
\text { declarações e ações }\end{array}$ & Integridade \\
\hline $\begin{array}{l}\text { Domínio da Ação e } \\
\text { dos Resultados }\end{array}$ & $\begin{array}{c}\text { Pedidos, ofertas, } \\
\text { promessas e reclamações }\end{array}$ & $\begin{array}{c}\text { Confiança, competência, } \\
\text { responsabilidade e } \\
\text { sinceridade }\end{array}$ & Dignidade \\
\hline $\begin{array}{c}\text { Domínio dos } \\
\text { Relacionamentos }\end{array}$ & $\begin{array}{l}\text { Escutar e confiança que } \\
\text { se constrói e reconstrói }\end{array}$ & $\begin{array}{c}\text { Quiebres, juízos } \\
\text { fundamentados, dar } \\
\text { autoridade para que } \\
\text { outros nos ensinem }\end{array}$ & Autenticidade \\
\hline $\begin{array}{c}\text { Domínio da } \\
\text { Aprendizagem }\end{array}$ & Reflexão, perguntas e juízos & Feedback e respeito & Legitimidade \\
\hline
\end{tabular}

Fonte: Lucena Filho et al. (2012).

Conforme Lucena Filho et al. (2012), considerando que as organizações são redes interdependentes de compromissos e que tais compromissos são estruturados a partir de tarefas, relações e identidades entre indivíduos e grupos, a gestão pode ser vista com um constante cuidado, através de um campo cíclico, baseado nos domínios ontológicos, de cada dimensão da tríade (T-R-I), que tem lugar "nas" e "através das" conversas interpessoais dentro das organizações. Essa concepção é apresentada na Figura 1.

\subsection{A Pesquisa}

Estudos correlatos já revelaram a importância das competências conversacionais para o desenvolvimento de equipes [Braga 2007], para a aprendizagem organizacional no contexto de projetos [Santos 2008], para uma boa gestão de projetos [Andrade 2009] e para o alinhamento estratégico entre a tecnologia da informação e o negócio [Brito 2010].

Esta pesquisa utiliza um questionário desenvolvido e testado por Braga (2007), Santos (2008) e Andrade (2009), baseado na autoavaliação proposta por BorgesAndrade e Lima (1983) e indicada por Carbone, Brandão e Leite (2005) para a identificação das lacunas de competências humanas existentes em uma organização. 


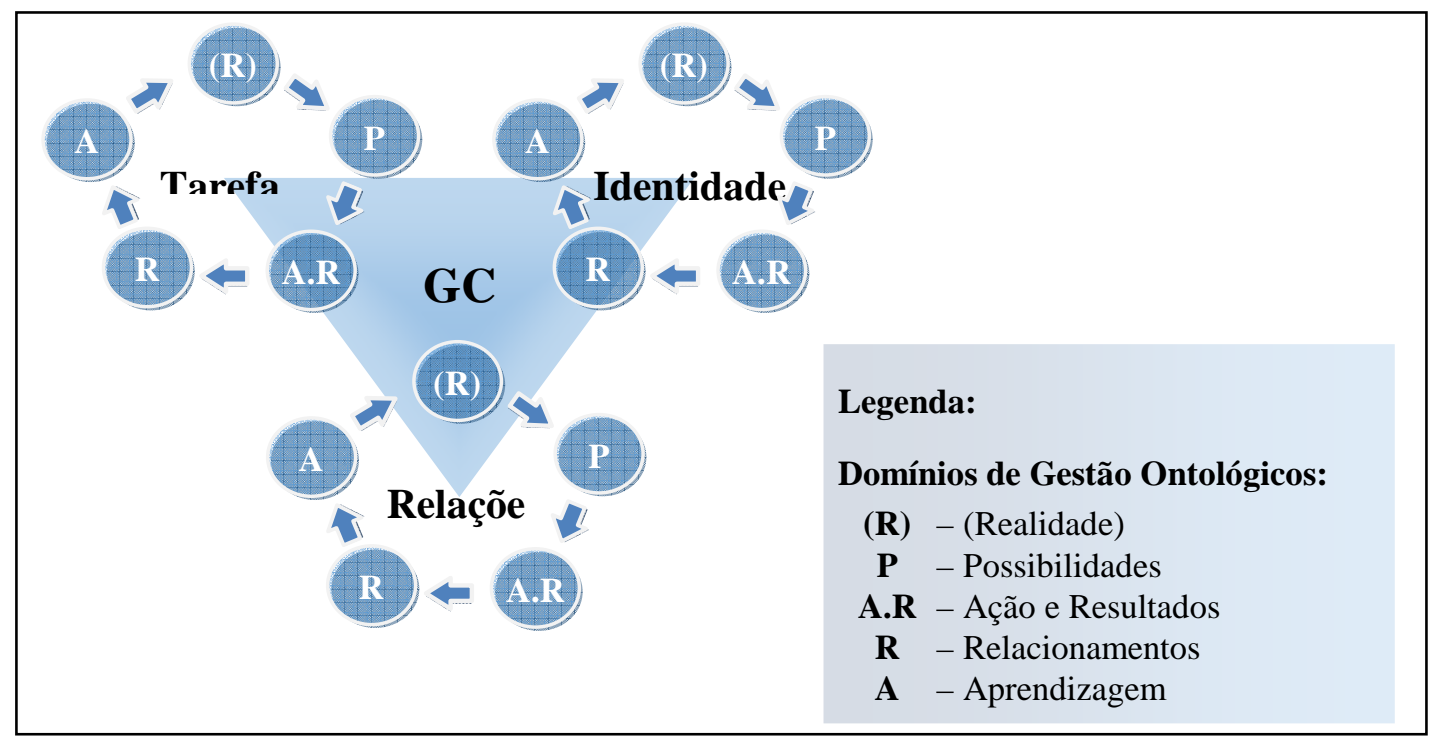

Figura 1 - Visão integrada das dimensões da tríade e dos domínios da gestão ontológica. Fonte: Lucena Filho et al. (2012).

Nesse questionário, cada questão se refere a um "comportamento observável na atuação do respondente na organização" [Braga 2007]. Esse comportamento corresponde a uma ou mais competências conversacionais. Para cada questão o respondente atribui um grau de importância ao referido comportamento para o desempenho de suas atividades e a frequência em que se vê atuando daquela forma. Tanto para a importância como para a frequência a resposta deve ser dada seguindo uma escala Likert que varia de zero a quatro, onde os respondentes são solicitados a informar o grau de concordância/discordância.

A equação utilizada para o cálculo da lacuna de competência, conforme Braga (2007), é: $\mathbf{N}=\mathbf{I} *(\mathbf{4}-\mathbf{F})$, onde $\mathbf{N}=$ Lacuna de competências; $\mathbf{I}=$ Grau de importância e $\mathbf{F}=$ Grau de frequência. Andrade (2009) classificou os possíveis valores das lacunas e a partir desses valores categorizou as lacunas como "Nula", "Baixa", "Mediana", "Alta" e "Muito Alta".

\section{Materiais e Métodos}

O procedimento metodológico foi baseado nos trabalhos de Braga (2007), Santos (2008) e Andrade (2009). Sendo que este último foi submetido a uma rigorosa validação semântica e sintática do questionário, à análise de confiabilidade, testes estatísticos e de correlação. Dada a validação desta pesquisa, optou-se por seguir essa mesma linha.

O público alvo da pesquisa focou em uma recente iniciativa de implantação de Governança Corporativa em um órgão secular do Poder Legislativo Federal. Tal iniciativa envolveu muitos projetos, em que atores de diversas áreas e de níveis hierárquicos variados se reuniram em torno de ideias, ações e decisões, ou seja, em um ambiente onde as conversas foram fundamentais para o estabelecimento de compromissos para o sucesso da iniciativa. Os questionários foram distribuídos para os participantes de seis projetos. Por se tratar de uma situação piloto e um grupo específico selecionado intencionalmente, este caso se caracteriza, segundo Antunes (2012), 
Honório e Lauris (2011), como amostra não probabilística intencional. Nesse caso os resultados não podem ser estatisticamente generalizados para a população, porque não se pode estimar o erro amostral.

A pesquisa é classificada quanto à natureza como aplicada e quanto à abordagem do problema como quantitativa, quanto aos fins como descritiva e quanto aos meios como bibliográfica e de campo [Gil 2010].

A pergunta de pesquisa é: como as conversas contribuem para a Governança Corporativa? O pressuposto é que a Governança Corporativa se faz com conversas e para que as conversas sejam efetivas e produzam os resultados desejados, as competências conversacionais são fundamentais. Como hipóteses secundárias, supõe-se que os participantes dos projetos da Governança Corporativa possuem lacunas de competências que podem afetar os resultados, e que o framework de gestão das conversas é um instrumento efetivo para a avaliação das competências conversacionais.

O escopo dessa pesquisa foi limitado às duas primeiras perspectivas do framework conversacional, referentes aos domínios da gestão da (Realidade) e das Possibilidades, por causa da limitação de tempo para a sua realização.

O primeiro passo foi realizar um estudo da literatura e dos trabalhos correlatos para identificação dos comportamentos relacionados às competências conversacionais necessárias para se fazer rodar o ciclo da gestão ontológica de maneira eficaz, segundo framework conversacional proposto por Lucena Filho et al. (2012).

Em seguida, esses comportamentos foram colocados em forma de assertivas que seriam lidas e avaliadas pelos respondentes. Os passos seguintes envolveram a estruturação e elaboração do questionário, análises semântica e sintática, definição da ferramenta de coleta e análise de dados, testes, aplicação do questionário, coleta e validação dos dados, e a análise dos dados.

\subsection{Estruturação do Questionário}

O questionário traz um bloco inicial com perguntas sobre dados demográficos e perguntas gerais sobre o trabalho realizado. Em seguida traz seis blocos com oito assertivas cada, referentes aos comportamentos que caracterizam as competências conversacionais relacionadas ao cruzamento das dimensões dos compromissos - Tarefa, Relações e Identidade - com os domínios da (Realidade) e das Possibilidades.

A seguir são explicados os objetivos que se busca em cada um desses blocos e os comportamentos identificados.

\subsubsection{Dimensão Tarefa X Domínio da (Realidade)}

Neste bloco as assertivas buscam identificar a utilização efetiva das distinções, das informações e das afirmações que visam evidenciar cada (Realidade). As perguntas chave são: "As informações, evidências e fatos que descrevem a realidade estão disponíveis e são suficientes? Existe o reconhecimento de que outras realidades podem estar fora do alcance da atual capacidade de observação?" [Lucena filho et al., 2012].

No Quadro 4 são apresentados os comportamentos que denotam se as pessoas buscaram conhecer a (realidade) com base em fatos e evidências e, a partir dessas, foram 
feitas afirmações verdadeiras e observáveis por todos os interlocutores. Além disso, procurou-se identificar se houve um compartilhamento das mesmas distinções, ou seja, se existiu um vocabulário comum com as compreensões dos termos utilizados no projeto, para que todos compartilhassem as mesmas visões. Buscou-se observar o reconhecimento de cada observação como verdadeira e o reconhecimento da própria observação como limitada às próprias capacidades do seu modelo mental.

Neste trabalho, uma observação relevante: tanto nos gráficos como nos quadros, utilizamos o fundo cinza para caracterizar o domínio da (Realidade) e o fundo verde para caracterizar o domínio das Possibilidades.

\section{Quadro 4 - Dimensão Tarefa X Domínio da (Realidade)}

\section{Bloco 1 - Comportamentos:}

1.1. Ao expressar minhas ideias apresento dados e exemplos que sustentam meu raciocínio e minhas conclusões.

1.2. Ao apresentar dados e exemplos me asseguro que sejam comprováveis e estejam disponíveis.

1.3. Ao apresentar dados e exemplos que sustentam minha observação e / ou opinião cuido para que eles sejam suficientes e relevantes tanto para ilustrar meu raciocínio quanto, principalmente, para garantir o cumprimento da tarefa que se tem em vista.

1.4. Reciprocamente, costumo pedir para que meu (s) interlocutor (es) apresente (m) dados e exemplos que sustentem sua (s) observação (ões) e / ou opinião (ões) no sentido de que estas sejam suficientes e relevantes tanto para ilustrar o raciocínio dele (s), quanto, principalmente, para garantir o cumprimento da tarefa que se tem em vista.

1.5. Quando alguém expõe a sua ideia, costumo repetir o que foi dito para checar com ele/a se o que entendi corresponde ao que ele/a de fato disse / quis dizer.

1.6. Reconheço que cada pessoa observa a (realidade) de forma diferente, pois distingue os fatos de acordo com seu próprio ponto de vista. (Esse é o propósito dos “()" em torno da palavra "realidade”. Reveja a figura do e-mail).

1.7. Reconheço que meu ponto de vista pode ser limitado pela minha capacidade de observação.

1.8. Para ter certeza que estou sendo bem compreendido costumo checar com meu (s) interlocutor (es) se ele (s) compartilha (m) do mesmo vocabulário, com as mesmas distinções e mesmos significados, sob as mesmas convenções sociais e técnicas.

Fonte: Os autores com base em [Lucena filho et al., 2012].

\subsubsection{Dimensão Tarefa X Domínio da Possibilidades}

No cruzamento da dimensão Tarefa com o domínio das Possibilidades buscam se as competências para suspender julgamentos, decidir e declarar. As perguntas chave são "Observa-se o passado, avaliando-o sem preconceitos, de maneira ampla, como um contexto gerador de possibilidades? Observa-se o futuro com a autoridade de quem pode decidir quais compromissos precisam ser sustentados?" [Lucena filho et al., 2012].

Nesse bloco o objetivo foi identificar a efetividade nas escolhas feitas e nas decisões tomadas pelos participantes e a capacidade de criar um contexto gerador de possibilidades para o futuro. Para isso, as pessoas observaram os comportamentos listados no Quadro 5 e responderam se foram capazes de suspender, ou seja, adiar os julgamentos para permitir um leque considerável de possibilidades e se as declarações eram feitas com maturidade. Questionou-se também se o passado foi avaliado de forma responsável, compartilhando a fundamentação e a linha de raciocínio em que foram 
baseados os juízos; se a intenção foi buscar a concepção de um valor útil e significativo tanto para as partes interessadas como para o cliente. E, por fim, se as declarações feitas foram suficientes para gerar resultados efetivos e se foram validadas pela autoridade competente para assumir o compromisso por si e pela equipe e sustentá-lo durante a ação.

\section{Quadro 4 -Dimensão Tarefa X Domínio das Possibilidades}

Bloco 2 - Comportamentos:

2.1. Quando outra pessoa expõe suas ideias busco adiar meus julgamentos e "suspender meus pressupostos" com o objetivo de escutá-la melhor.

2.2. Busco ampliar significativamente o leque de alternativas, deixando fluir a criatividade minha e de meus colegas, deixando para depois a decisão de julgar qual alternativa é a mais adequada para se atingir o objetivo do trabalho.

2.3. Ao avaliar alternativas, levo em consideração a experiência do passado para prever as consequências de cada ideia que está sendo discutida, compartilhando a fundamentação e a linha de raciocínio das minhas conclusões.

2.4. Ao tomar decisão sobre qual alternativa é a mais adequada busco aquela capaz de gerar um resultado efetivo, útil e significativo tanto para as partes interessadas como para toda a organização.

2.5. Na tomada de decisão avalio se é oportuno fazer isso agora e se é politicamente viável.

2.6. Na tomada de decisão avalio como eu posso me preparar para as consequências, se terei recursos, tempo e capacidade suficientes para honrar os compromissos assumidos.

2.7. Somente tomo decisão quando me sinto com autoridade suficiente para assumir compromissos que possam ser sustentados por mim e pela minha equipe.

2.8. Na tomada de decisão avalio se todas as partes estão assumindo compromissos de forma consistente com suas capacidades e com a autoridade condizente com as declarações feitas.

Fonte: Os autores com base em [Lucena filho et al., 2012]

\subsubsection{Dimensão Relações X Domínio da (Realidade)}

A dimensão das Relações aplicada ao domínio da (Realidade) busca a essência da coletividade para se permitir a observação de novas distinções e conexões. As perguntas chaves são "Estão abertas as possibilidades para que pessoas com novas distinções possam fazer interpretações e conexões diferentes da realidade? Existe abertura para apreciar e acolher novas percepções da realidade?" [Lucena filho et al., 2012].

Nesse bloco, o objetivo foi buscar identificar as competências para cuidar das relações interpessoais para criar um ambiente de cooperação e solidariedade, conforme mostrado no Quadro 6. Avaliou se o respondente reconhece que seu modelo mental pode criar pontos cegos impedindo-o de fazer distinções e conexões de causa e efeito entre fatos e consequências que explicam as situações experimentadas. Se ele estava aberto para novas distinções e conexões. Se ele atuou com valores intrínsecos ao cultivo das relações em prol da coletividade, como a inclusão, o reconhecimento e a ética do respeito. Se esses valores foram cultivados dando abertura para que pessoas com novas distinções pudessem fazer interpretações e conexões diferentes das suas e, pessoalmente, estando aberto para apreciar e acolher novas percepções da realidade. Estas posturas favorecem o comprometimento, a união das pessoas e a formação de uma equipe coesa [Kofman 2002]. 


\section{Quadro 5 - Framework - Dimensão Relações X Domínio da (Realidade)}

Bloco 3 - Comportamentos:

3.1. Eu cuido da minha relação com as outras pessoas para criar um ambiente de cooperação e solidariedade.

3.2. Ao expor as minhas idéias, costumo deixar claro que aquilo que digo é a minha posição pessoal e não uma verdade absoluta.

3.3. Eu tenho uma postura acolhedora quando outra pessoa expõe suas ideias, demonstrando interesse, inclusive, por interpretações e compreensões diferente das minhas.

3.4. Eu sou cuidadoso (a) ao expor fatos e evidências que possam contrariar as ideias tradicionalmente aceitas por outras pessoas.

3.5. Eu estou aberto para aceitar pontos de vista antagônicos de outras pessoas.

3.6. Ao falar, levo em consideração a forma de me expressar (tom de voz, postura, clima emocional).

3.7. Ao expor a minha posição dou oportunidade às pessoas para perguntar e solicitar esclarecimentos.

3.8. Eu busco me colocar no lugar do outro, compreender a situação particular do outro, seus interesses, habilidades, sucessos, fracassos, oportunidades e problemas.

Fonte: Os autores com base em [Lucena filho et al., 2012]

\subsubsection{Dimensão Relações X Domínio das Possibilidades}

Nesse cruzamento estão os pontos fundamentais para a inovação e para a coerência entre declarações e ações. As perguntas chave são "Existe espaço para a espontaneidade, o desatino e a irreverência de maneira que ideias criativas e possibilidades novas possam ser expressas e, se o caso, acolhidas? São os propósitos comuns explícitos e orientados à cocriação de soluções?" [Lucena filho et al., 2012].

Com as assertivas desse bloco, apresentadas no Quadro 7, o objetivo foi identificar se há um ambiente propício para a inovação, que vai além do ambiente físico e entra no ambiente mental e afetivo da equipe. Para se atingir resultados de forma inovadora e compartilhada os seguintes aspectos foram observados: o propósito comum, o compromisso de criar juntos, o ambiente alegre, descontraído e desinibido para que mentes sem travas busquem um novo futuro. Não há criatividade se a mente não estiver aberta e desinibida. Observaram-se os vínculos de confiança que se formam a partir da coerência entre as declarações e ações. Falar de erros e fracasso abertamente é um exemplo de maturidade e só é possível em um ambiente onde exista a confiança [Kofman 2002]. 


\section{Quadro 6 -Dimensão Relações X Domínio das Possibilidades}

Bloco 4 - Comportamentos:

4.1. Ao iniciar uma reunião de trabalho, eu procuro deixar claro a todos os participantes o assunto a ser tratado, a razão e a importância das atividades e os objetivos a serem cumpridos até o final da reunião.

4.2. Procuro estimular a parceria, o amplo diálogo e a participação de todos os colegas para a co-criação (criação coletiva) das possibilidades de ação, consciente de que procedendo dessa forma favoreço o compartilhamento de objetivos, o comprometimento das pessoas e o sucesso dos resultados.

4.3. Participo de brincadeiras e dou abertura para a espontaneidade, a descontração, o desatino e a irreverência, consciente de que essa postura favorece um bom clima no ambiente de trabalho e possibilita que ideias criativas e possibilidades novas possam ser expressas e, se o caso, acolhidas.

4.4. Se estou coordenando um trabalho, defino junto com os participantes os objetivos, as metas e a forma de trabalhar em um processo de diálogo e alinhamento de interesses.

4.5. Eu sou capaz de consentir e me comprometer com uma ação que seja mais de interesse da organização como um todo do que com meu interesse particular.

4.6. Tanto ao falar quanto no escutar, me coloco no lugar da outra pessoa, para melhor compreender sua situação particular, seus interesses, habilidades e problemas.

4.7. Sinto-me seguro para falar de fracassos e erros em um clima espontâneo com o objetivo de favorecer decisões e possibilidades de ação.

4.8. Ao discutir possibilidade para a ação deixo espaço para que as pessoas possam assumir compromissos por coisas que são apaixonadas.

Fonte: Os autores com base em Lucena Filho et al. (2012).

\subsubsection{Dimensão Identidade X Domínio da (Realidade)}

O respeito é a principal distinção observada nesse cruzamento. As perguntas chave são "As pessoas estão conscientes de que a sua maneira de observar a realidade decorre dos modelos mentais que possuem? As diferenças entre as pessoas são reconhecidas e, como tal, geram respeito?" [Lucena filho et al., 2012].

Nas assertivas desse bloco, apresentadas no Quadro 8, o que se procurou foi a essência do reconhecimento do indivíduo. Os entrevistados foram avaliados pela capacidade de reconhecer que cada pessoa é um ser humano único, com sua individualidade caracterizada pelo seu modelo mental e intrínseco a ele, seus valores. Feita esta distinção, foi avaliado se ela serviu para uso das competências da aceitação e do respeito entre as pessoas. Sem a aceitação não há a comunhão de valores e sem o respeito não há relações verdadeiras.

\section{Quadro 7 -Dimensão Identidade X Domínio da (Realidade)}

\section{Bloco 5 - Comportamentos:}

5.1. Reconheço que tudo o que eu observo depende dos meus sentidos físicos, da minha personalidade, da cultura da comunidade que vivi e que vivo hoje, dos meus conhecimentos, do meu idioma, da minha experiência, das minhas vivências, da minha história pessoal e que tudo isso configura o meu modelo mental.

5.2. Reconheço que cada pessoa tem um modelo mental diferente e que por isso uma pessoa é capaz de enxergar partes da realidade que outra pessoa não consegue.

5.3. Eu não consigo perceber tudo que existe na realidade porque meu modelo mental limita minhas percepções.

5.4. Para ampliar a minha percepção da realidade eu preciso que outra pessoa com distinções diferentes da minha me mostre as evidências e que me explique como ela percebe tais fatos. 
5.5. Eu reconheço as diferenças entre as pessoas e por isso sou capaz de respeitar suas percepções e suas afirmações acerca da realidade que observam.

5.6. Ao expor minha visão, procuro expor também meus conceitos e minhas convicções, me comprometendo em sustentá-la independente das consequências advindas de minhas afirmações.

5.7. Quanto maior a quantidade de pessoas com percepções diferentes da realidade, compartilhando suas visões com respeito e reconhecimento, mais completa será a realidade observada pelo grupo e maior será a possibilidade de encontrar soluções efetivas para os objetivos perseguidos.

5.8. Respeito a capacidade de auto-reflexão e autocrítica dos outros, pois reconheço que tanto eu como os outros estamos em um processo de aprendizado, em níveis diferentes e que o compartilhamento de visão favorece o aprendizado coletivo.

Fonte: Os autores com base em Lucena Filho et al. (2012).

\subsubsection{Dimensão Identidade X Domínio das Possibilidades}

Nesse bloco, a busca é pela essência da postura do indivíduo consigo mesmo: a integridade. As perguntas chave são "As pessoas têm a capacidade de sustentar as escolhas que fazem, comprometidas com a coerência de suas ações? Existe abertura para que, quando incoerências sejam observadas, possam ser apontadas de maneira a garantir a integridade das pessoas e dos propósitos?" [Lucena filho et al., 2012].

A busca foi pelo respeito consigo mesmo a partir da integridade, observada quando a pessoa se compromete com aquilo que é capaz de sustentar, conforme apresentado no Quadro 9. Além disso, essas escolhas devem ser legítimas, e para isso devem ser feitas com liberdade de dizer sim ou não às possibilidades. Então, buscou-se investigar se houve abertura para que incoerências fossem observadas e pudessem ser apontadas de maneira a garantir a integridade das pessoas e dos propósitos da organização. Na tomada de decisão também se avaliou se todas as partes estavam assumindo compromissos de forma consistente com suas capacidades e com a autoridade condizente com as declarações feitas.

\section{Quadro 8 -Dimensão Identidade X Domínio das Possibilidades}

\section{Bloco 6 - Comportamentos:}

6.1. Sinto-me realizado (a) quando os resultados do trabalho atingem tanto as metas e objetivos institucionais como as minhas metas e objetivos pessoais.

6.2. Tenho capacidade de sustentar as escolhas que faço.

6.3. Minhas ações são coerentes com os compromissos por mim assumidos.

6.4. Faço minhas escolhas com liberdade para dizer sim ou não, sem me sentir constrangido (a) ou pressionado (a).

6.5. Na tomada de decisão avalio se todas as partes estão assumindo compromissos de forma consistente com suas capacidades e com a autoridade condizente com as declarações feitas. Quando percebo incoerências procuro apontá-las de maneira a garantir a integridade das pessoas e dos propósitos do projeto.

6.6. Mesmo consentindo e me comprometendo com uma ação que seja de interesse da organização, eu deixo bem claro a todos os participantes a minha decisão e a minha posição contrária, fundamentando o meu raciocínio e a minha percepção.

6.7. Sou sincero (a) com minha equipe, isto é, não deixo de conversar sobre temas que são relevantes para a organização, ainda que seja uma conversa delicada.

6.8. Nas conversas comigo, realizadas na organização, dou abertura às pessoas para dizerem abertamente o que pensam e/ou o que sentem sem ameaçá-las (velada ou explicitamente) nem criticá-las "negativamente". 
Fonte: Os autores com base em Lucena Filho et al. (2012).

\subsection{Escala de Autoavaliação}

Após ler cada assertiva os respondentes do questionário foram orientados a avaliar dois quesitos: a Frequência (F) e a Importância (I) conforme escalas de autoavaliação baseadas no trabalho de Braga (2007). No quesito "Importância", foi pedido que o respondente marcasse, conforme seu ponto de vista pessoal, um valor de 0 a 4 que representasse a importância do comportamento apresentado para a efetividade das suas ações em busca de melhores resultados para sua organização. A escala usada foi a seguinte: 0 - Não é importante; 1 - É pouco importante; 2 - É razoavelmente importante; 3 - É muito importante; e 4 - É essencial. No quesito "Frequência" foi pedido que assinalasse um valor de 0 a 4 que melhor refletisse a frequência na qual o respondesse se visse atuando conforme a assertiva. A escala usada foi: 0 - Nunca; 1 De vez em quando; 2 - Com razoável frequência; 3 - Com grande frequência; e 4 Sempre.

As lacunas de competências conversacionais $(\mathbf{N})$ foram calculadas conforme a fórmula $\mathbf{N}=\mathbf{I} *(\mathbf{4}-\mathbf{F})$ e classificadas conforme apresentadas no Quadro 10.

\section{Quadro 10 - Categorias das lacunas de competências}

\begin{tabular}{|c|c|c|}
\hline Lacuna & Categoria & Descrição da classificação da lacuna de competência \\
\hline $\mathrm{N}=0$ & Lacuna Nula & $\begin{array}{l}\text { A importância atribuída ao comportamento é zero ou a frequência do } \\
\text { mesmo é máxima, no caso dessa pesquisa, igual a quatro. }\end{array}$ \\
\hline $\mathrm{N}=1$ ou 2 & Lacuna Baixa & $\begin{array}{l}\text { A frequência é maior em até duas unidades do que a importância, ou seja, } \\
\text { a relação frequência-importância é positiva. }\end{array}$ \\
\hline $\begin{array}{l}\text { N de } 3 \text { até } \\
6\end{array}$ & $\begin{array}{l}\text { Lacuna } \\
\text { Mediana }\end{array}$ & $\begin{array}{l}\text { A frequência é igual à importância atribuída (com exceção dos extremos } \\
0 ; 0 \text { ou } 4 ; 4) \text {, porém a importância é menor que o valor máximo }(=4) \text {; ou a } \\
\text { frequência é uma unidade menor que a importância. }\end{array}$ \\
\hline $\mathrm{N}=8$ ou 9 & Lacuna Alta & A frequência é menor em duas unidades que a importância. \\
\hline $\mathrm{N}=12$ & $\begin{array}{l}\text { Lacuna } \\
\text { Muito Alta }\end{array}$ & A frequência é menor em três unidades que a importância. \\
\hline $\mathrm{N}=16$ & Esquizofrenia & $\begin{array}{l}\text { É quando se atribui uma importância máxima para um comportamento } \\
\text { (Import. =4) e nunca se comporta como tal }(\text { Freq. }=0) \text {. }\end{array}$ \\
\hline
\end{tabular}

Fonte: Os autores, adaptado de Andrade (2009).

\section{Apresentação e Discussão dos Resultados}

Os resultados dessa pesquisa são apresentados em três perspectivas: (i) análise demográfica e caracterização do grupo; (ii) análise coletiva do grupo e (iii) análise individual. Considera-se comportamento cada assertiva do questionário e lacuna de competência conversacional ao resultado da aplicação da fórmula $\mathrm{N}=\mathrm{I} *(4-\mathrm{F})$, (descrita no item 0), às respostas dos entrevistados ao comportamento, onde $\mathbf{I}$ é a importância por eles atribuída e $\mathbf{F}$ é a frequência com que utilizam o comportamento.

\subsection{Dados demográficos}

O convite para responder ao questionário foi enviado por e-mail para todos os participantes envolvidos nas iniciativas da Governança Corporativa do órgão do Legislativo Federal estudado, totalizando cinquenta pessoas. Foram respondidos 25 
questionários. Conforme exposto no item 3, os resultados desta análise se limitam a descrição do grupo de respondentes, não sendo possível generalizá-los para a população.

Pelos dados demográficos da Tabela 1 pode-se observar que $80 \%$ dos respondentes possuem mais de 40 anos de idade. Sessenta por cento possuem especialização em nível de pós-graduação, $24 \%$ mestrado, $4 \%$ doutorado e o restante, possui segundo grau completo.

Em relação ao tempo de casa $40 \%$ têm três anos ou menos de casa, $40 \%$ têm de onze a vinte anos de casa e $20 \%$ têm mais de 26 anos de casa. Não respondentes com tempo de casa entre 3 e 10 anos, fato que se explica pelo longo período em que a casa não fez concurso público. Há uma representatividade de $40 \%$ de novatos (com menos de três anos de casa) nos projetos de Governança Corporativa.

Tabela 1 - Dados Demográficos

\begin{tabular}{|c|c|c|c|c|c|}
\hline Quantidade de questionários: & \multirow[t]{2}{*}{25} & \multirow[t]{2}{*}{$100 \%$} & Pessoas que se identificaram & $\#$ & $\%$ \\
\hline & & & Nome & 14 & $56 \%$ \\
\hline Quanto tempo trabalha na casa & \# & $\%$ & E-mail & 14 & $56 \%$ \\
\hline Até 3 anos & 10 & $40 \%$ & & & \\
\hline Mais de 3 até 5 anos & 0 & $0 \%$ & Sexo & \# & $\%$ \\
\hline Mais de 5 até 10 anos & 0 & $0 \%$ & Masculino & 18 & $72 \%$ \\
\hline Mais de 10 até 15 anos & 6 & $24 \%$ & Feminino & 7 & $28 \%$ \\
\hline Mais de 15 até 20 anos & 4 & $16 \%$ & & & \\
\hline Mais de 20 até 25 anos & 0 & $0 \%$ & Idade & $\#$ & $\%$ \\
\hline Mais de 25 até 30 anos & 5 & $20 \%$ & Pessoas que informaram a Idade: & 14 & $56 \%$ \\
\hline Mais de 30 anos & 0 & $0 \%$ & Idade mínima & 27 & - \\
\hline & & & Idade máxima & 55 & - \\
\hline Escolaridade & $\#$ & $\%$ & Até 30 anos & 1 & $7 \%$ \\
\hline $2^{\circ}$ Grau Completo & 1 & $4 \%$ & de 31 a 35 & 0 & $0 \%$ \\
\hline Superior Completo & 2 & $8 \%$ & de 36 a 40 & 2 & $14 \%$ \\
\hline Especialização/Pós-Graduação & 15 & $60 \%$ & de 41 a 45 & 5 & $36 \%$ \\
\hline Mestrado & 6 & $24 \%$ & de 46 a 50 & 3 & $21 \%$ \\
\hline Doutorado & 1 & $4 \%$ & de 51 a 55 & 3 & $21 \%$ \\
\hline
\end{tabular}

Fonte: Os autores.

\subsection{Resultados Globais}

Os resultados apresentados na Erro! Fonte de referência não encontrada. foram calculados a partir da média aritmética de todas as frequências e de todas as importâncias de todos os comportamentos de todos os respondentes para cada célula (cruzamento "Dimensão X Domínio" do framework).

Tabela 2 - Resultados Globais consolidados pela média

\begin{tabular}{|c|c|c|c|c|c|c|c|c|c|}
\hline \multirow{2}{*}{$\begin{array}{l}\text { Dimensões Compromissos } \\
\text { Domínios de } \\
\text { Atuação Ontológicos }\end{array}$} & \multicolumn{3}{|c|}{ Tarefa } & \multicolumn{3}{|c|}{ Relações } & \multicolumn{3}{|c|}{ Identidade } \\
\hline & $F_{\text {med }}$ & $I_{\text {med }}$ & $\mathbf{N}_{\text {med }}$ & $F_{\text {med }}$ & $I_{\text {med }}$ & $\mathbf{N}_{\text {med }}$ & $F_{\text {med }}$ & $\mathrm{I}_{\text {med }}$ & $\mathbf{N}_{\text {med }}$ \\
\hline Domínio da (Realidade) & 2,59 & 3,41 & 4,81 & 2,93 & 3,21 & 3,44 & 2,98 & 3,36 & 3,42 \\
\hline
\end{tabular}




\begin{tabular}{|c|c|c|c|c|c|c|c|c|}
$\mathrm{F}_{\text {med }}$ & $\mathrm{I}_{\text {med }}$ & $\mathbf{N}_{\text {med }}$ & $\mathrm{F}_{\text {med }}$ & $\mathrm{I}_{\text {med }}$ & $\mathbf{N}_{\text {med }}$ & $\mathrm{F}_{\text {med }}$ & $\mathrm{I}_{\text {med }}$ & $\mathbf{N}_{\text {med }}$ \\
\hline 2,82 & 3,48 & $\mathbf{4 , 1 0}$ & 2,86 & 3,27 & $\mathbf{3 , 7 3}$ & 3,09 & 3,46 & $\mathbf{3 , 1 5}$ \\
\hline
\end{tabular}

Fonte: Os autores

A Lacuna Média de competências foi calculada com base nesses valores, usando a fórmula $\mathbf{N}_{\text {med }}=\mathbf{I}_{\mathbf{m e d}}{ }^{*}\left(\mathbf{4}-\mathbf{F}_{\mathbf{m e d}}\right)$. Observa-se que em todos os cruzamentos do framework a importância ficou acima de 3 que corresponde a "muito importante" e que a frequência ficou entre 2 e 3, ou seja, entre "razoável" e "grande frequência". De modo que, em geral, o grupo apresenta lacunas de competências classificadas como "mediana", em todos os cruzamentos. Pelas médias mostradas no framework observa-se que as maiores lacunas se apresentam na dimensão da Tarefa e as menores lacunas na dimensão da Identidade.

No Gráfico 1 são analisadas as Lacunas Médias de competências para cada comportamento. Estas lacunas de competências foram calculadas a partir da média aritmética de todas as frequências e de todas as importâncias de todos os respondentes para cada comportamento.

Vale lembrar que neste trabalho, utilizamos o fundo cinza para caracterizar o domínio da (Realidade) e o fundo verde para caracterizar o domínio das Possibilidades.

\section{Gráfico 1 - Lacunas Médias por Comportamento}

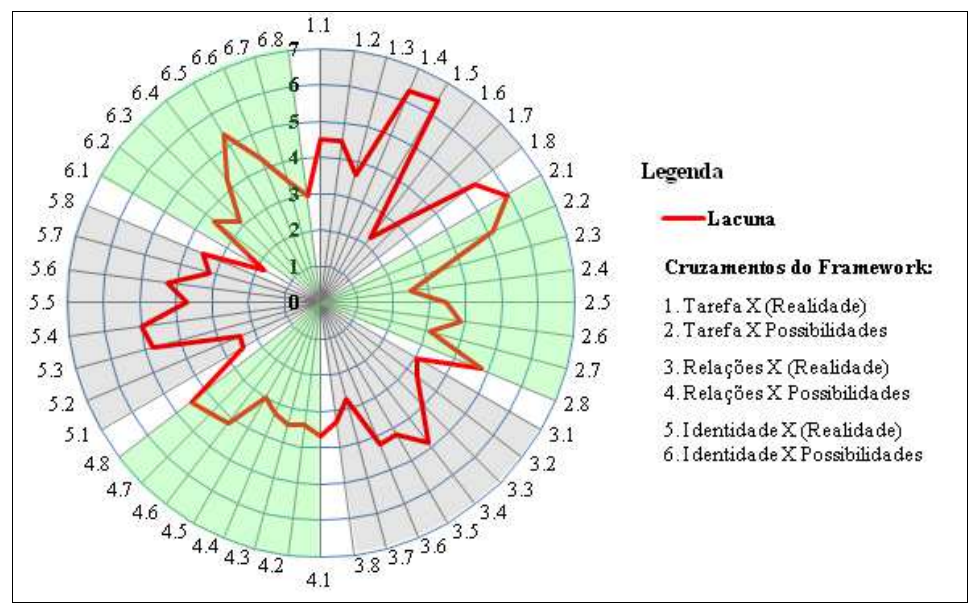

Fonte: Os autores

A numeração em torno do gráfico de radar corresponde a cada assertiva do questionário. O primeiro numeral corresponde a cada um dos seis cruzamentos do framework conversacional que, por sua vez, corresponde às distinções básicas da conversação, conforme relacionadas no Quadro 3:

\section{Dimensão Tarefa:}

1. (Realidade), distinções, informação e afirmações

2. Suspender julgamentos, decidir e declara

\section{Dimensão Relações:}

3. Distinções novas e conexão 


\title{
4. Coerência entre declarações e ações
}

\section{Dimensão Identidade:}

\author{
5. Respeito \\ 6. Integridade
}

O segundo numeral corresponde aos comportamentos de 1 a 8 relacionados nos Quadros 4 a 9. No gráfico de radar quanto mais próximo do centro, menor será a lacuna da competência conversacional. Ou seja, o desejável é que o desenho seja o mais fechado possível.

Nota-se que as maiores lacunas estão na dimensão da tarefa e correspondem aos comportamentos 1.4 e $1.5^{2}$ no domínio da (Realidade) e 2.1 e $2.2^{3}$ no domínio das possibilidades.

Os comportamentos 1.4 e 1.5 correspondem ao "uso consciente da escada de inferências" Kofman (2002, v. I, p. 132), um método para evitar más interpretações e garantir uma mútua, recíproca e mais completa visão da realidade.

Os comportamentos 2.1 e 2.2, sendo menos frequentes, tendem a limitar a inovação, a criatividade e a busca de alternativas mais efetivas. Nesse caso, as organizações tendem a "cair na armadilha de definir o problema e sua solução com demasiada rapidez e obviedade, no "piloto automático"” Kofman (2002, v. I, p. 239).

Neste mesmo gráfico pode-se fazer também a análise das lacunas mais baixas. No cruzamento "2. Tarefa X Possibilidades", por exemplo, observam-se os comportamentos 2.4 e $2.7^{4}$ com as lacunas mais baixas:

Tais comportamentos levam a compromissos sustentáveis tanto pela autoridade que toma as decisões quanto pelos critérios. "São justamente esses critérios de avaliação o que se deduz da visão" [Kofman 2002, v. I, p. 179].

Esta análise pode ser feita para todos os comportamentos do framework. Pode-se observar, conforme hipótese secundária de pesquisa, que existem lacunas de competências conversacionais que podem afetar os resultados organizacionais. Esse gráfico apresenta um diagnóstico do grupo analisado e pode servir de base para uma ação de capacitação coletiva em competências conversacionais.

2 1.4. Costumo pedir para que meu interlocutor apresente dados e exemplos que sustentem sua observação e/ou opinião no sentido de que estas sejam suficientes e relevantes tanto para ilustrar o raciocínio, quanto, principalmente, para garantir o cumprimento da tarefa em vista. / 1.5. Quando alguém expõe a sua ideia, costumo repetir o que foi dito para checar com ele se o que entendi corresponde ao que ele de fato quis dizer.

3 2.1. Quando outra pessoa expõe suas ideias busco adiar meus julgamentos e "suspender meus pressupostos" com o objetivo de escutá-la melhor. / 2.2. Busco ampliar significativamente o leque de alternativas, deixando fluir a criatividade minha e de meus colegas, deixando para depois a decisão de julgar qual alternativa é a mais adequada para se atingir o objetivo do trabalho.

4 2.4. Ao tomar decisão sobre qual alternativa é a mais adequada busco aquela capaz de gerar um resultado efetivo, útil e significativo tanto para as partes interessadas como para toda a organização. I 2.7. Somente tomo decisão quando me sinto com autoridade suficiente para assumir compromissos que possam ser sustentados por mim e pela minha equipe. 
A visão integrada do framework nos permite uma análise ainda mais efetiva. Do ponto de vista do ciclo de gestão, por exemplo, se a visão da (Realidade) for incompleta (comportamentos $1.4,1.5$ ) e as alternativas porem pouco exploradas (comportamentos 2.1 e 2.2), as decisões, mesmo que bem encaminhadas (comportamentos 2.4 e 2.7), podem estar fundamentadas em critérios deduzidos de uma visão incompleta e de soluções pouco inovadoras.

\subsection{Resultados Individuais}

Para os resultados individuais foram calculadas as lacunas de competências para cada comportamento de cada respondente do questionário. Deste modo foi possível analisar onde cada indivíduo apresenta lacunas de competências conversacionais e comparar com a média.

O Gráfico 2 mostra um exemplo das lacunas de competências conversacionais de um indivíduo comparado com a média. O gráfico de radar com preenchimento em vermelho $(\square)$ corresponde às lacunas médias e o gráfico de radar com a borda em azul (一) corresponde às lacunas para cada assertiva do indivíduo.

Nesse exemplo a pessoa apresenta lacunas altas na gestão da (Realidade) das Tarefas e das Possibilidades. Os comportamentos 1.8 e $3.2^{5}$ apresentam lacunas de competências muito altas. Tais comportamentos ajudam as pessoas a compartilhar e acolher de forma efetiva a compreensão mútua daquilo que cada uma afirma, evitando mal-entendidos. Por outro lado, na dimensão da Identidade o indivíduo apresenta lacunas baixas e nulas.

O resultado desse mapeamento gráfico individual possibilita verificar onde cada respondente precisa aperfeiçoar suas competências conversacionais, possibilitando também uma ação de capacitação individualizada.

5 1.8. Para ter certeza que estou sendo bem compreendido costumo checar com meu (s) interlocutor (es) se ele (s) compartilha $(\mathrm{m})$ do mesmo vocabulário, com as mesmas distinções e mesmos significados, sob as mesmas convenções sociais e técnicas. / 3.2. Ao expor as minhas ideias, costumo deixar claro que aquilo que digo é a minha posição pessoal e não uma verdade absoluta. 


\section{Gráfico 2 - Lacunas de Competências Conversacionais de um Indivíduo}

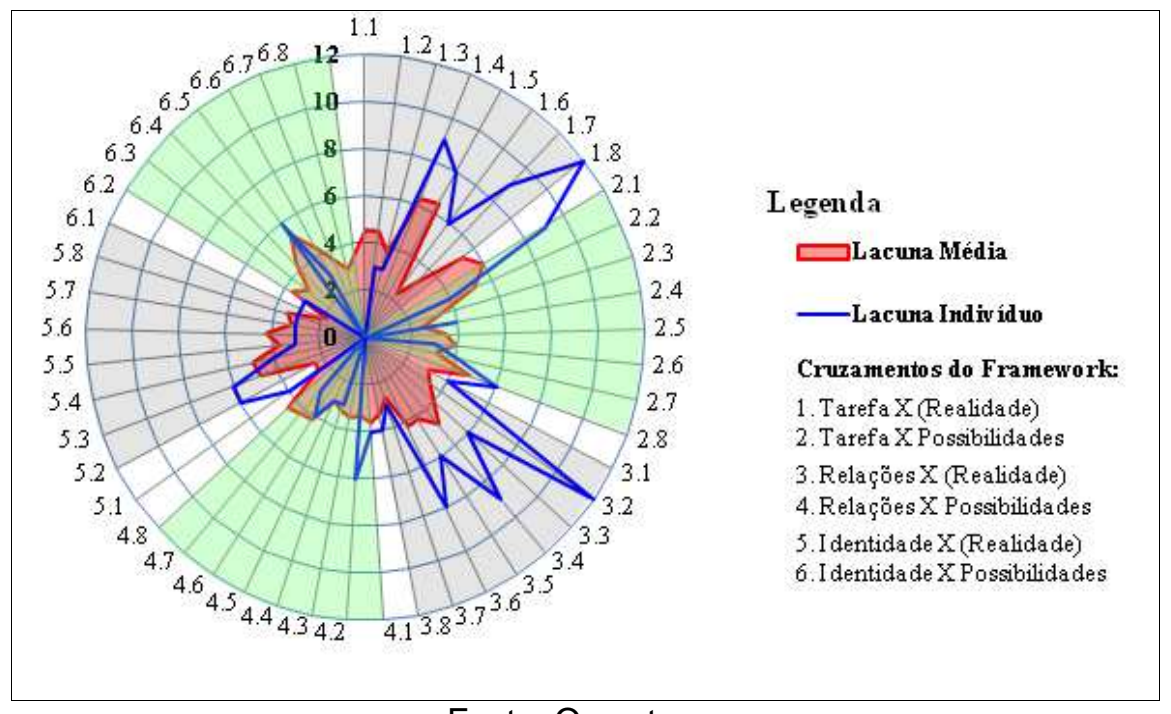

Fonte: Os autores

Em um aspecto geral, este indivíduo apresenta algumas lacunas altas na gestão da (Realidade) das Tarefas e das Possibilidades. Os comportamentos 1.8 e $3.2^{6}$ apresentam lacunas de competências muito altas. Tais comportamentos ajudam as pessoas a compartilhar e acolher de forma efetiva a compreensão mútua daquilo que cada uma afirma, evitando mal-entendidos. Por outro lado, na dimensão da Identidade, relacionadas ao respeito e à integridade, o indivíduo apresenta lacunas baixas e nulas. Pode-se inferir que este indivíduo preza pela identidade, considerando o respeito e a integridade, tanto sua como do grupo, as algumas lacunas altas nos blocos 1 e 3 podem prejudicar a observação da realidade e a visão das soluções.

A análise gráfica de outro indivíduo, apresentada no Gráfico 3, mostra um comportamento nas dimensões da Tarefa e das Relações conforme a média do grupo, porém na gestão da identidade apresenta lacunas altas. Quando isso ocorre, denota-se que a pessoa não cuida tanto do respeito e da integridade, fatores fundamentais para a impecabilidade na gestão de seus compromissos. Com isso, apesar do indivíduo apresentar baixas lacunas de competências para enxergar a realidade e buscar possibilidades de ação, as decisões por ele tomadas correm o risco de não chegarem ao fim, sem atingir os resultados desejados.

\section{Gráfico 3 - Lacunas de Competências Conversacionais de outro Indivíduo}




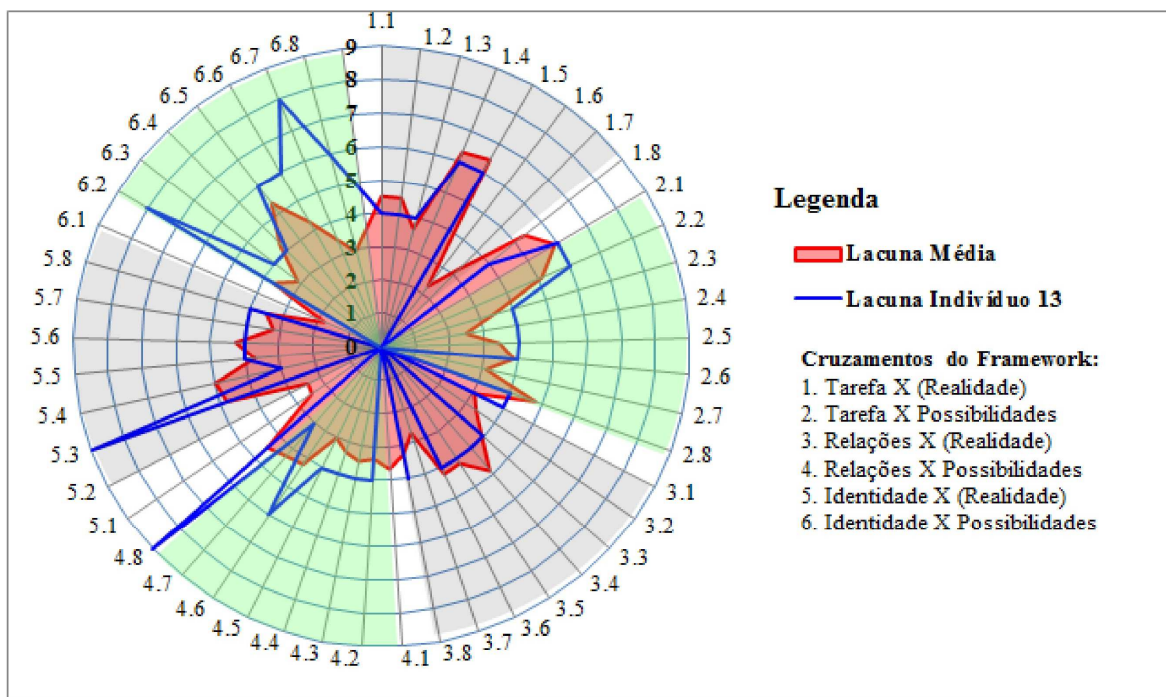

Fonte: Os autores

O resultado desse mapeamento gráfico individual possibilitou verificar onde cada respondente precisa aperfeiçoar suas competências conversacionais, possibilitando também uma ação de capacitação individualizada.

\section{Considerações Finais}

O principal objetivo deste artigo foi investigar como as conversas contribuem para a Governança Corporativa ou, noutros termos, como ter competências conversacionais favorece a efetividade do trabalho de governantes, gestores e gerentes no cumprimento de seus compromissos institucionais e geração de resultados significativos para as organizações a que pertencem. Os objetivos secundários foram a investigação das lacunas de competências conversacionais de alguns desses personagens e o uso de um framework de gestão de conversas, que já vem sendo desenvolvido há algum tempo por um dos autores, em um ambiente real de projetos.

O grupo de pessoas, participantes e responsáveis pela Governança Corporativa de uma instituição pública do Poder Legislativo Federal, na qual a investigação foi conduzida, identificou a importância das competências conversacionais para as atividades desenvolvidas na organização. Os objetivos secundários da pesquisa foram atingidos ao se constatar, nos comportamentos do grupo sob investigação a existência de lacunas de competências conversacionais nos integrantes do mesmo. Essas lacunas, mensuradas pela diferença entre a importância atribuída pelo próprio gestor em seu comportamento, ao se permitir observar-se (e ser observado) em suas ações com vistas à avaliação de efetividade na realização de seu trabalho, face a frequência de uso pelo gestor desse mesmo comportamento, permitiram aferir a importância de ser efetivo no uso de competências conversacionais para o cumprimento dos objetivos institucionais. A análise dessas lacunas sob o prisma do framework de gestão conversacional mostrou não só como "boas práticas" conversacionais contribuem para a geração de bons resultados na organização, como mostrou também que o framework utilizado é um instrumento efetivo para uma análise organizacional e individual das competências conversacionais da organização como um todo e das pessoas que a constituem em seus complexos interrelacionamentos. 
Uma das contribuições relevantes deste trabalho é situar a Governança Corporativa como peça fundamental para a mudança de um sistema centrado na propriedade para um sistema voltado para a sociedade do conhecimento. Conforme Echeverría (1999), a Governança Corporativa tem o papel de construção do futuro, uma vez que as transformações históricas têm nas organizações seu principal motor. Para que esse papel seja efetivo é necessário que haja uma mudança de um modelo mental tecnicista para um modelo mental mais humanizado, como mencionam Flores (1996), Kofman (2002), Migueles et al. (2009) e Sznifer (2012).

Uma vez que a Governança Corporativa abrace esta responsabilidade, vai encontrar neste trabalho e em outros trabalhos correlatos um instrumental para que possa efetivar tais mudanças. A abordagem conversacional mostra-se capaz de integrar as dimensões técnicas e humanas para gerar resultados mais efetivos e mudanças mais duradouras.

Da análise empreendida pelo framework pode-se observar a relação de continuidade entre os domínios de gestão ontológicos. Como foi visto, quando a gestão da (realidade) é mais completa, o gestor tem mais elementos para deduzir critérios de escolha apropriados, quando a gestão das possibilidades é mais eficiente, as alternativas poderão ser mais numerosas, mais criativas e mais inovadoras. Isso não quer dizer que a gestão dos 5 domínios apontados no modelo utilizado no framework seja um processo linear. É fato que há uma lógica na sequência de ações necessárias para se ir de um ponto (Realidade atual) a outro avaliado como Possibilidade (Realidade desejada). Sem essas Ações, bem coordenadas, não se gerará os Resultados almejados. Tampouco sem as Relações geradoras de vínculos de confiança entre os atores envolvidos.

Estamos diante de um sistema intrinsecamente complexo, seja em sua dinâmica de funcionamento (complexidade dinâmica, em que causas e efeitos em geral estão afastados no tempo e no espaço, dificultando sua compreensão com base apenas na experiência direta); seja pelas formas por vezes desconhecidas e imprevisíveis com que suas manifestações se reproduzem (complexidade generativa); ou seja, ainda, pela complexidade social inerente à própria natureza do sistema, em que as pessoas envolvidas vêem as coisa de formas muito diferentes, o que, via de regra, polarizam e emperram a fluidez das atividades organizacionais (KAHANE, 2007).

Há ainda outro aspecto importante a ressaltar sobre essa forma não linear de se ver e abordar a governança corporativa, conforme mencionado em relação aos 5 domínios da gestão ontológica. Trata-se da não linearidade com que as 3 dimensões da Tríade se fazem presentes na estrutura dos compromissos institucionais: a Tarefa (T), as Relações (R) e a Identidade (I) da instituição [Flores 1996; Kofman 2002]. Na gestão de compromissos institucionais com base nessas dimensões é preciso considerar que essas dimensões (T, R, I) "dançam" juntas e que essa dança só flui quando há um equilíbrio "sadio", ou "equilíbrio sistêmico", entre elas. Noutras palavras, é essencial que os compromissos institucionais que permeiam a gestão da organização (em seus vários níveis: governança, gestão ou gerência) aconteçam de forma sistemicamente equilibrada no conjunto das dimensões mencionadas. Isso porque:

- Cumprir com a Tarefa (T) "a qualquer custo", quebrando os relacionamentos, ou seja, a partir de relacionamentos que não geram vínculos de confiança, termina minando a Identidade da Instituição; 
- Por outro lado, descuidar da Tarefa para não ameaçar a Identidade (I) do outro é uma formula certa para garantir a mediocridade dos resultados institucionais;

- Por fim, cuidar da identidade (individual ou da organização) sem considerar o impacto que ela sofre ou provoca na Relação (R) com o outro, ainda que premido pela pressão do cumprimento de uma tarefa, é poluir a rede com relações potencialmente conflituosas e inefetivas.

Resumindo: "dançar" essa dança da gestão de compromissos na governança corporativa de uma organização (aí incluídos os níveis de gestão e gerência) a partir do desequilíbrio é um caminho certo (e, infelizmente, ainda muito comum nas organizações) para não se atingir resultados, para gerar ressentimentos e para nos sentirmos reféns do sistema e de nós mesmos.

Temos consciência de que temos um vasto campo de pesquisa e desenvolvimento pela frente. Por um lado, mais técnico, para considerar o ciclo completo da gestão ontológica, nesta pesquisa restrita ao escopo de, apenas, dois de seus cinco domínios. Por outro lado, num sentido mais amplo, por reconhecer a forma ainda tímida em nossa proposta atual de humanizar as "práticas de governança" em nossas organizações. Isso nos estimula a dar continuidade à pesquisa e ao desenvolvimento de nosso framework conversacional no sentido de que este se transforme num efetivo instrumento de Gestão Organizacional, sentido amplo.

\section{Referências}

Andrade, E. C. S. D. (2009). Conversas: o fator chave para o gerenciamento de projetos. Dissertação (mestrado). Universidade Católica de Brasília, DF.

Antunes, R. (2012). Amostragem. Sondagens e estudos de opinião, WordPress.

Borges-Andrade, J. E.; Lima, S. M. V. (1983). Avaliação de necessidades de treinamento. In Tecnologia Educacional, v. 12, n. 54, p. 5-14, set./out.

Braga, S. D. O. (2007). O coaching ontológico como instrumento de desenvolvimento de equipes de trabalho. Dissertação (mestrado). Universidade Católica de Brasília, DF.

Brasil. Presidência da República. Casa Civil. (2007). Decreto 6.021, de 22 de janeiro de 2007: Cria a Comissão Interministerial de Governança Corporativa e de Administração de Participações Societárias da União - CGPAR. Disponível em: http://www.planalto.gov.br/ccivil_03/_Ato2007-2010/2007/Decreto/D6021.htm.

Tribunal de Contas da União - TCU. (2013). Referencial básico de governança / Tribunal de Contas da União. - Brasília: TCU. 57 p. Disponível em: http://portal.tcu.gov.br/lumis/portal/file/fileDownload.jsp?inline=1\&fileId=8A8182A 24F0A728E014F0B2E3ED6213C.

Brito, J. C. B. (2010). Alinhamento Estratégico entre TI e Negócio: uma abordagem conversacional. Dissertação (mestrado). Universidade Católica de Brasília

Carbone, P. P.; Brandão, H. P. B.; Leite, J. B. D. (2005). Gestão por competências e gestão do conhecimento. Rio de Janeiro: Ed. FGV. ISBN 9788522505135. 
COSO. (2007). Committee of Sponsoring Organizations of the Treadway Commission. Gerenciamento de Riscos Corporativos - Estrutura Integrada. EEUU: AICPA.

CVM. (2002). Comissão de Valores Mobiliários. Cartilha: Recomendações da CVM sobre Governança Corporativa. Rio de Janeiro: CVM.

Echeverría, R. (1999). A empresa emergente: a confiança e os desafios da transformação. Caracas: Newfield Consulting. (2005). Ontologia del Lenguaje. Chile: J. C. Sáez Editor.

Flores, F. (1996). The Impact of IT on Business. In Conference at the ACM 50th. Anniversary. California.

Gil. A. C. (2010). Como elaborar projetos de pesquisa. 5a.ed. São Paulo: Atlas.

Heifetz, R.; Laurie, D. (1997). The Work of Leadership. Harvard Business Review, January-February.

Hidalgo, I. (2009). Gestión Ontológica. Caracas: Mil Palabras Servícios Editoriales.

IBGC. (2009). Instituto Brasileiro de Governança Corporativa. Código das Melhores Práticas de Governança Corporativa. São Paulo: IBGC.

ISACA. (2016). Information Systems Audit and Control Association. COBIT 5. USA: Rolling Meadows. Disponível em: http://www.isaca.org/cobit/pages/default.aspx.

Kofman, F. (2002). Metamanagement: a nova consciência dos negócios. Edition. São Paulo: Antakarana Cultura Arte Ciência/Willis Harman House, 3 volumes.

Lucena Filho, G. J. (2010). Competências conversacionais: Um diferencial no gerenciamento de projetos. MundoPM, ago./set. 2010. ISSN 18078095.

Lucena filho, G. J. et al. (2012). A Technontological Framework to Conversations for KM: Conception and Potential Applications. In 9th International Conference on Intellectual Capital, Knowledge Management \& Organisational Learning - ICICKM, Colômbia.

Migueles, C. et al. (2009). Liderança baseada em valores: caminhos para a ação em cenários complexos e imprevisíveis. Rio de Janeiro: Campus, ISBN 9788535236934.

Morgan, G. (2002). Imagens da Organização. $2^{a}$ ed. São Paulo: Atlas, 2002.

OCDE. (2004). Organização para a Cooperação e o Desenvolvimento Econômico. Os Princípios da OCDE sobre o governo das sociedades.

Santos, I. M. G. L. (2008). Competências relacionadas à aprendizagem organizacional em equipes de projetos. Dissertação (mestrado). Universidade Católica, Brasília.

Sznifer, M. F. (2012). Crie um futuro diferente para sua empresa. Mundo Corporativo, Rádio CBN. Disponível em: https://www.youtube.com/watch?v=iUv2vorfuI0.

Weill, P.; Ross, J. W. (2006). Governança de TI, Tecnologia da Informação. São Paulo: M. Books do Brasil.

Winograd, T.; Flores, F. (1988). Understanding Computers and Cognition: A New Foundation for Design. Norwood, NJ: Ablex. ISBN 9780893910501. 